\title{
THE IMPACT OF NATURAL CONDITIONS ON THE DEVELOPMENT AND COMPETITIVENESS OF THE LUBUSKIE VOIVODESHIP
}

\author{
Edward JAKUBOWSKI \\ University of Zielona Góra, Department of Regional Policy, Zielona Góra; e.jakubowski@wez.uz.zgora.pl, \\ ORCID: 0000-0002-5853-3745
}

Purpose: This publication presents the most important natural resources in the Lubuskie Voivodeship, which have very large importance for regional development in terms of tourism, supra-regional but also domestic.

Design/methodology/approach: The method of statistical data analysis and source materials was used in the work.

Findings: The richness of the voivodeship are forests and wilderness, with numerous landscape parks, reserves and monuments of nature as well as with animals living in the wild. An important aspect in the tourist landscape of the Lubuskie Voivodeship are castles, churches and manor houses and palaces related to the history of the region. Today, a large proportion of tourists seek to learn about folklore, tradition, folk creativity, as well as regional cuisine. The voivodeship offers a wide range of cultural, sporting, entertainment and artistic events. It should be added that as one of the few regions in Poland, the Lubuskie Voivodeship may offer enotourism as an attraction.

Originality/value: The analysis carried out in the article is addressed to people interested in regional policy in the aspect of the impact of natural conditions on the development and competitiveness of Polish regions.

Keywords: regional development, region, natural resources, competitiveness.

\section{Introduction}

The economic importance of the landform has a huge impact on the possibility of introducing to the environment generally understood forms of economic activity such as agriculture, forestry, settlement, and above all tourism. The form of the land brings enormous potential for development, for activities related to the proper selection of crops, soil protection, afforestation of land or designing construction projects (Macias, Bródka, 2014, p. 136). 
The plant cover of Poland has outstanding values. Several factors imposed this. Poland lies on the border of two Central European geobotanical provinces, i.e. Lowland-Upland and Mountain. The large vertical diversity from the Baltic Sea to the Tatra Mountains causes a stronger diversity of our flora. In the territory of our country there are also numerous transitive species from the west and east, reaching our territories ending their ranges. These factors cause a great wealth of our plant cover. The second factor of good preservation of our plant cover is related to the fact that, compared to Europe, we still have the largest forest refuges and swamppeat flora. Despite the huge transformation of our vegetation, caused by human interference, the remains of forests have survived. In various parts of the country there are refuges of the forest flora, including the Lubuska. So we have extremely valuable floristic complexes that deserve special care and protection (Kozłowski, 1983, p. 82).

A characteristic feature of the contemporary Polish climate is the large variability of weather conditions. The relatively fast migration of barric highs and barric lows over Europe contributes to this. Over the area of Poland, moist air masses coming from the Atlantic with drier masses of continental origin clash. Climatic conditions in the mountainous areas of southern Poland are significantly affected by a decrease in temperature with increasing altitude. Its consequence is a clear climate stratification in the Carpathians and Sudetes. A sign of Poland's rising continental climate towards the east are aggravating winters. Oceanism is indicated by the advantage of autumn rainfall over spring precipitation. The prevalence of autumn precipitation is in southwestern Poland. The western part of the country is also characterized by more frequent occurrence of mid-winter thaws, causing rivers to gather. These features have contributed to the climate of Poland, which is often called transitory (Starkel, 1991, p. 17).

In the climate classification, there is a border in Poland between moderate, warm and rainy, and boreal, snow-forest climate. The area of Poland is intersected by annual isoamplitudes of 20-23C. They are within the boundary between the oceanic and continental climate. Seasonal, changing from year to year distribution of climatic factors and mainly conditioned flowing water and vegetation, affects the quality, course and intensity of sculptural processes in Poland. Climate-related factors determine the type of sculpture. For these reasons, attempts to separate modern morphoclimatic zones refer to individual climate classifications. Polish lands almost entirely belong to the forest zone dropping leaves for the winter. The dominant natural plant communities in our country were deciduous forests, and to a lesser extent mixed forests.

At present, coniferous forests prevail in the Polish forests, because most of them suitable for deciduous and mixed forests have been used for arable land. The most significant feature of contemporary Polish vegetation is its transience to neighbouring areas. Plant cover changes from west to east, as continentalism increases. In Polish lands, numerous plant communities with an oceanic climate are disappearing, and in their place there are or are growing in importance of coniferous forests, characteristic of the lowland areas of the Eurasian continent. In southwestern Poland, the relative share of brown soils increases among zonal soils, 
and the mug-wort soils in the north and east. South-eastern ends of Poland is a dense range of steppe humus areas and the narrow strip of grey forest soils characteristic of forest-step adjacent to it from the north. Regional diversity of the animal world also refers to the spatial diversity of the natural environment. The majority of non-transitive species in our native fauna, whose share is close to $40 \%$, reach the northern and north-western border in Poland, while the least eastern and south-eastern. Progressive deforestation of many areas of our country initiated a period of anthropogenic fauna reconstruction. The transitional nature of the contemporary Polish natural environment is therefore determined by climate-related features, i.e. water cycle, flora and fauna, soils and sculpting processes. The current natural environment of Poland is transformed by man. The geographical location of any territory is of fundamental importance for all regional considerations. This is a significant feature that gives rise to the separateness of territories. Contemporary composition of the Polish flora has been determined as a result of climate change and the spread of species during the post-glacial period. The last glaciation created the conditions for the spread of the steppe tundra in southern Poland, but eventually the disappearance of the Scandinavian continental glacier caused a re-entry of the forest (Kondracki, 1978, p. 149). Vegetation and animal world in a state similar to the original one survived only in national parks and reserves.

\section{Natural values of the Lubuskie Voivodeship}

As the area of Poland is very rich in nature, nevertheless this paper will focus on the Lubuskie region, its values and conditions of this beautiful land. The Lubuskie Voivodeship occupies the central-western part of Poland with an area of $13989 \mathrm{~km}^{2}(4,5 \%$ of the country area). The structure of the Lubuskie Voivodeship surface according to the directions of use is as follows, i.e. forests and tree stands $51,0 \%$, agricultural land $41,0 \%$, communication areas $2,7 \%$, surface water $1,7 \%$, housing estate $1,4 \%$, wasteland $1,3 \%$, other areas $0,9 \%$. The Lubuskie Voivodeship borders on the north with the West Pomeranian Voivodeship, on the east with the Wielkopolskie Voivodeship, and on the south with the Dolnośląskie Voivodeship. This beautiful region has 1009,2 thousand inhabitants. The voivodeship is divided into 12 land districts (poviats). The districts include 83 communes, including 9 municipal, 33 urban-rural and 41 rural. There are 42 cities, 1376 villages and 1017 parishes (village administrative units) in the voivodeship. The Lubuskie Land belongs to the Lubuskie - Lower Silesia climate region. The climate in the north of the voivodeship, in the press of the Notec and Warta River valleys, is of a transitional nature between the cool and quite humid of Pomeranian region and the warmer and drier part of the central and southern part of the Lubuskie - Lower Silesia region. The region is one of the warmest in the country. In Stubice there is Polish heat pole, where the highest maximum temperatures in Poland are recorded. 
The entire area of the province is located in the Baltic catchment area, and in the central part of the Odra river basin.

South of the Torun - Eberswald Pradolina on both sides of the Odra in Poland and Germany extends a macro-region called the Lubuskie Lake District. It differs in significant natural features from the Greater Poland Lakeland located further to the east. Lubuskie Lake District hills exceed $200 \mathrm{~m}$ above sea level in places, while deep gutters fill the lakes. The climate here is more humid than farther east, the afforestation of the area is considerable, and the occurrence of beech is characteristic for forest complexes (Kondracki, 1978, p. 293). In the Lubuskie Voivodeship there are beautiful lakes, which makes this region very rich in beautiful landscapes, has a huge impact on the competitiveness of this region.

The central register of nature protection forms kept by the General Director for Environmental Protection includes in the Lubuskie Voivodeship: 2 national parks - "Warta Mouth" and partly Drawieński National Park, 67 nature reserves, 8 landscape parks, 41 protected landscape areas, 409 ecological lands, 12 complexes of nature and landscape, 2 documentation sites for geological formations and 1262 nature monuments (Przemysław, Demidowicz, Konopczyński, 2018).

These are undoubtedly beautiful landscapes and wonderful forests. There are a total of 519 lakes in the voivodeship, including 36 in the size range of 50-100 ha and 26 with an area of more than 100 ha. The total area of Lubuskie lakes is 13009,8 ha, which is $0,93 \%$ of the voivodeship's area. It shows the richness and advantages of this region as well as in terms of competitiveness. The Sławskie Lake is the largest lake in this region with a water surface of 817,3 ha. It is often called by the youth "Lubuskie Sea", by the elders "Silesian Sea". The islands occupy 10,6 ha of the lake, there are, among others Bird Island, Cormorant Island, Wild Island. There are also several bays, including Miejska, Radzyńska, Lubiatowska, Krępińska. The Sławskie Lake together with Obrzyca forms the beginning of the 200-kilometer canoe trail to Santok near Gorzów Wilkp. Along the shores of the lake there are many holiday resorts. In the season it is up to 40 thousand guests there, mainly from Lower Silesia and the Lubuskie Land. It is worth adding that they began to be developed only in 1927, when Sława municipality received permission from the county to make the lake available for water sports. Today, it is the region's largest area for sailors to show off. There is a free public beach at the Sławskie Lake in Sława.

The area of the Lubuskie Voivodeship is covered in forests in 48,7\% (681, 6 thousand ha), which is the largest forest cover rate in the country. This should be regarded as incredible, and certainly for another reason to choose this region for rest. Since 2000, the forest area has increased by $0,6 \%$ ( 8960 ha). In the habitat structure, coniferous habitats prevail, with pine as the dominant species, they occur on almost $90 \%$ of the forest area. In the Lubuskie, every second hectare is a forest, so the term "Lubuskie sea" is often used to refer to Lubuskie forests. Most often pine can be found there, which is why it is called the "kingdom of Pine". The dendrological garden at the Nature and Forestry Education Center in Wysokie Jeziora is 
worth visiting. In addition to Coulter pine, there are 30 other species of pines. It is also a collection of cones. The educational trail "On the ravines" is worth recommending, as well as the historical and natural path "From Sass to the forest", which leads from the High Lakes to the beautiful Palace in Brody located a few kilometres away. This is undoubtedly a great opportunity to create tourist routes, from hiking in the forests to visiting the monuments of the region.

In the surrounding forests it is possible to find Octopus Pine, a tree with a trunk, whose trunk grows up to eight branches, which is undoubtedly unheard of. Moreover, it is also possible to see "dancing pine trees", or "Forest Candelabra", fancifully bent pines that give the impression of dancing. However, Lubuskie forests are not only pine forests. There are two national parks in the voivodeship, i.e. Drawieński and "Warta Mouth" with a total area without buffer zone of 13606,4 ha. Eight landscape parks were created in the voivodeship, i.e. Łagowski, Pszczewski, Barlinecko-Gorzowski, "Ujście Wart”, Gryżyński, Krzesiński, Przemęcki and "Luk Mużakowa". The total area of landscape parks is currently almost 80000 ha. There are also 55 nature reserves in the voivodeship with a total area of over 3,6 thousand ha, of which 32 objects are forest reserves, 7 peat bogs, 6 fauna, 4 water, 4 floristic and 2 steppe. In 2006 three new reserves were created, i.e. 2 forest reserves - Żurawno and Mierkowskie Suche Bory in the Żary dictrict and one steppe - Gorzowskie Murawy in Gorzów Wielkopolski (Demidowicz, Konopczyński, 2006, p. 9).

In the Lagowsko-Sulęcin Landscape Park it is also possible to see beech forests, in combination with the azure water of the Łagowskie and Trześniowskie Lakes creates the magic of this place. For lovers of forests and paths not yet trampled it is a beautiful Landscape Park. By the shore of Trześniowskie Lake, a path resembling mountain climates leads to the "Buczyna Łagowska" Nature Reserve, where even 150-year-old beeches grow (https://zbierajsie.pl/5-powodow-lubic-lubuskie, 22/09/2019).

The Trześniowskie Lake is more wild because its shores are very steep and the lake itself is deeper. It is 4,7 km long and 60 meters wide. Its turquoise colour is due to the large depth and the presence of limestone. The Trześniowskie Lake is the 10th deepest lake in Poland. With a depth of 58,8 meters, it also encourages divers who come to enjoy underwater life here. So, this is another reason why it is recommended to come there. Apparently, visibility is incredible there. It is a region with many bike paths, fishing piers and water equipment rentals. The National Park "Warta Mouth" and its buffer zone is also noteworthy. This place is also impressive and recommendable, above all it differs in character from other forests. Currant alder, or alder forest growing in swampy habitats will impress everyone who finds it. The Lubuskie Voivodeship is therefore created to be in the bosom of nature. There are many walking, cycling paths, observation towers or sports paths. According to the inhabitants, the most beautiful lake is the Lagowskie Lake. The water is turquoise and the forests so beautiful that it is breath-taking. The Łagowskie Lake is a gutter lake with an area of 
82 hectares. It is also worth visiting the Joanite Castle in the centre of Lagów. It is possible to move on canoes and pedal boats on the Lagowskie Lake.

The legendary knights lived in the 600-year-old castle in Łagów between the two lakes for over 450 years. It survived during the war, so today it is possible to admire its beautiful interiors. It is worth noting that the Joannites are in other words order from Malta. It comes from the medieval brotherhoods and knightly orders that arose on the wave of the first Crusades. The name comes from the Latin word "Joannes" or "John". Today, the order has about 10000 members, 160 of them are Poles. Established in 1083, the Order of the Knights of Malta survived to this day. A fortified tower dominates the castle, which is visible from a distance of several kilometres. From the top of the tower of the castle in Łagów there is a beautiful view of the countryside. This location was of great strategic importance on the border of Greater Poland, Pomerania and Brandenburg (https://www.styl.pl, 22/09/2019). If the canoe trail is preferred, one will certainly find a diverse network for themselves along the canals of Postomia and Warta. However, rivers are not only wide and swift streams of water, but also their deltas and backwaters. It is possible to admire them from around the mouth of the Warta river. The Lubuskie Voivodeship is located in Poland, where the glacier worked intensively. Hence, numerous lakes and moraine hills as well as a dense network of rivers. One of the most interesting places is the Muskau Arch, which is the glacier's frontal moraine area. Through its activities, land rich in mineral elements accumulated in this place, which was later used for mining activities.

In the area of the frontal moraine of the Muskau Arch and the place where decades ago coal and clay mines operated, the only Colourful Anthropogenic Lake District in Poland was created. It is possible to see there over 100 colourful lakes on the Polish side. In total, there are over 400 on both sides of the border. There are intense green waters, azure coves, rusty red reservoirs, and rainbow lakes. Certainly, they are a great attraction of this region, rare and admirable. They owe their colours to the presence of mineral elements in the substrate. However, this fairy-tale landscape also includes the lunar landscape resulting from the activities of underground and open-cast mines. It should also be mentioned that the wine tradition in the vicinity of Zielona Góra dates back to the twelfth century, when settlers from Flanders or Wallonia came together with vine varieties. The vines took on surprisingly very well there.

The most famous element of the Zielona Góra celebration is the Wine Procession. In addition, a Wine Market is being built around the Town Hall, where it is possible to learn about wine traditions, viticulture and take advantage of many artistic attractions. Considering the virtues of this beautiful region, its unique places, every traveller will find a place for himself, one may rediscover these places. Undoubtedly, this area can compete with numerous countries around the world. It has beautiful monuments, charming forests and many tourist attractions. All these natural conditions create great opportunities thanks to which this will affect the further development of this region of our country. 


\section{Tourism in the Lubuskie Voivodeship}

Indicators of tourist traffic intensity in the Lubuskie Voivodeship in relation to the number of actual inhabitants placed them in the top ten (places from 6-10 among 16 voivodeships) with a value lower than the national average, while other relative measures characterizing tourism of the Lubuskie Voivodeship were lower, placing them on place 11-13.

At the end of July 2018 in the Lubuskie Voivodeship, the surveyed population of tourist accommodation establishments (having 10 or more beds) consisted of 300 facilities. 217 of them offered all-year seats $(72,3 \%$, with the national average constituting $69,6 \%$ ). In the analysed period, there is a relatively constant number of accommodation facilities participating in the survey, oscillating in the range from 290 to 300 . The accommodation facilities of the voivodeship offered 18,5 thousand of bed places, which constituted $2,3 \%$ of the total number of bed places in Poland (nearly a $3 \%$ share measured by the number of bed objects). On average, there were 2 tourist accommodation establishments per $100 \mathrm{~km}^{2}$ of the Lubuskie Voivodeship (in the country - 3,5). On average, there were 18 beds per 1000 Lubuskie residents (21 in Poland).

In the Lubuskie Voivodeship, more than half of the hotels (43, i.e. $65,2 \%$ ) were mediumclass facilities, marked with the 3 - and 2-star category, 5 hotels $(7,6 \%)$ had the 4 -star category, there were no hotels with the highest 5 -star category. (Statistical Office in Zielona Góra, 30.05.2018).

Table 1.

Tourist accommodation facilities

\begin{tabular}{|c|c|c|c|c|c|c|c|c|}
\hline \multirow{4}{*}{ Name } & \multicolumn{8}{|c|}{ In total } \\
\hline & \multicolumn{2}{|c|}{ total facilities } & \multicolumn{2}{|c|}{ year-round facilities } & \multicolumn{2}{|c|}{ total beds } & \multicolumn{2}{|c|}{ all-year beds } \\
\hline & 2016 & 2018 & 2016 & 2018 & 2016 & 2018 & 2016 & 2018 \\
\hline & [fac.] & [fac.] & [fac.] & [fac.] & [bed] & [bed] & [bed] & [bed] \\
\hline POLAND & 10509 & 11076 & 7214 & 7709 & 749191 & 798723 & 521938 & 561525 \\
\hline LUBUSKIE & 299 & 300 & 207 & 217 & 19023 & 18512 & 10989 & 11083 \\
\hline
\end{tabular}

Source: Local Data Bank of the Statistical Office, https://bdl.stat.gov.pl (11.09.2019).

As of 31 July 2018, 18512 beds were waiting for travellers in tourist accommodation establishments. In the total number of places -11083 , i.e. $59,9 \%$, there were beds available for tourists throughout the year. In comparison with 2016, the share of year-round places in the total number of beds increased by 2,1 percentage points. One tourist facility offered an average of 62 beds (63 a year earlier, and 64 in 2016). 
Table 2.

Tourist accommodation establishments divided into facilities

\begin{tabular}{|c|c|c|c|c|c|}
\hline Name & Facilities & Facilities, places and rooms & Year & Value & \begin{tabular}{|l|} 
Unit of \\
measure
\end{tabular} \\
\hline \multirow{53}{*}{ 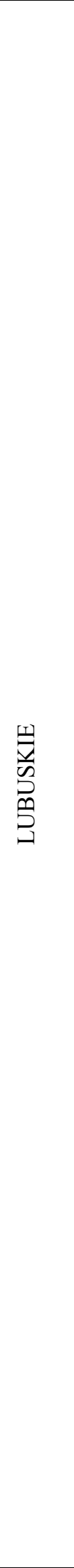 } & in total & total facilities & 2016 & 299 & Fac. \\
\hline & in total & total facilities & 2018 & 300 & Fac. \\
\hline & in total & total beds & 2016 & 19023 & Bed \\
\hline & in total & total beds & 2018 & 18512 & Bed \\
\hline & Hotels & total facilities & 2016 & 65 & Fac. \\
\hline & Hotels & total facilities & 2018 & 66 & Fac. \\
\hline & Hotels & total beds & 2016 & 4614 & Bed \\
\hline & Hotels & total beds & 2018 & 4824 & Bed \\
\hline & Hotels & total rooms & 2016 & 2397 & - \\
\hline & Hotels & total rooms & 2018 & 2482 & - \\
\hline & Motels & total facilities & 2016 & 15 & Fac. \\
\hline & Motels & total facilities & 2018 & 14 & Fac. \\
\hline & Motels & total beds & 2016 & 687 & Bed \\
\hline & Motels & total beds & 2018 & 642 & Bed \\
\hline & Motels & total rooms & 2016 & 354 & - \\
\hline & Motels & total rooms & 2018 & 328 & - \\
\hline & guesthouses & total facilities & 2016 & 13 & Fac. \\
\hline & guesthouses & total facilities & 2018 & 13 & Fac. \\
\hline & guesthouses & total beds & 2016 & 678 & Bed \\
\hline & guesthouses & total beds & 2018 & 672 & Bed \\
\hline & guesthouses & total rooms & 2016 & 301 & - \\
\hline & guesthouses & total rooms & 2018 & 306 & - \\
\hline & other hotel facilities & total facilities & 2016 & 41 & Fac. \\
\hline & other hotel facilities & total facilites & 2018 & 43 & Fac. \\
\hline & other hotel facilities & Total beds & 2016 & 1560 & Bed \\
\hline & other hotel facilities & Total beds & 2018 & 1516 & Bed \\
\hline & other hotel facilities & Total rooms & 2016 & 793 & - \\
\hline & other hotel facilities & Total rooms & 2018 & 697 & - \\
\hline & Boarding houses & Total facilities & 2016 & 1 & Fac. \\
\hline & Boarding houses & Total facilities & 2018 & 0 & Fac. \\
\hline & Boarding houses & total beds & 2016 & 20 & Bed \\
\hline & Boarding houses & Total beds & 2018 & 0 & Bed \\
\hline & youth hostels & Total facilities & 2016 & 2 & Fac. \\
\hline & youth hostels & Total facilities & 2018 & 2 & Fac. \\
\hline & youth hostels & Total beds & 2016 & 65 & Bed \\
\hline & youth hostels & Total beds & 2018 & 80 & bed. \\
\hline & school youth hostels & Total facilities & 2016 & 8 & Fac. \\
\hline & school youth hostels & Total facilities & 2018 & 7 & Fac. \\
\hline & school youth hostels & Total beds & 2016 & 390 & Bed \\
\hline & school youth hostels & Total beds & 2018 & 445 & Bed \\
\hline & holiday centres & Total facilities & 2016 & 28 & Fac. \\
\hline & holiday centres & Total facilities & 2018 & 27 & Fac. \\
\hline & holiday centres & Total beds & 2016 & 2894 & Bed \\
\hline & holiday centres & Total beds & 2018 & 2710 & Bed \\
\hline & summer camp centres & Total facilities & 2016 & 4 & Fac. \\
\hline & summer camp centres & Total facilities & 2018 & 4 & Fac. \\
\hline & summer camp centres & Total beds & 2016 & 559 & Bed \\
\hline & summer camp centres & Total beds & 2018 & 561 & Bed \\
\hline & training and recreation centres & Total facilities & 2016 & 23 & Fac. \\
\hline & training and recreation centres & Total facilities & 2018 & 22 & Fac. \\
\hline & training and recreation centres & Total beds & 2016 & 2568 & bed \\
\hline & training and recreation centres & Total beds & 2018 & 2354 & Bed \\
\hline & tourist cottage complexes & Total facilities & 2016 & 22 & Fac. \\
\hline
\end{tabular}


Cont. table 2.

\begin{tabular}{|c|c|c|c|c|}
\hline tourist cottage complexes & Total facilities & 2018 & 21 & Fac. \\
\hline tourist cottage complexes & Total beds & 2016 & 1339 & Bed \\
\hline tourist cottage complexes & Total beds & 2018 & 1237 & Bed \\
\hline Camping & Total facilities & 2016 & 4 & Fac. \\
\hline Camping & Total facilities & 2018 & 4 & Fac. \\
\hline Camping & Total beds & 2016 & 605 & Bed \\
\hline Camping & Total beds & 2018 & 605 & Bed \\
\hline camping sites & Total facilities & 2016 & 14 & Fac. \\
\hline camping sites & Total facilities & 2018 & 9 & Fac. \\
\hline camping sites & Total beds & 2016 & 1665 & Bed \\
\hline camping sites & Total beds & 2018 & 1180 & Bed \\
\hline Hostels & Total facilities & 2016 & 0 & Fac. \\
\hline Hostels & Total facilities & 2018 & 1 & Fac. \\
\hline Hostels & Total beds & 2016 & 0 & Bed \\
\hline Hostels & Total beds & 2018 & 20 & Bed \\
\hline guest rooms/private lodgings & Total facilities & 2016 & 11 & Fac. \\
\hline guest rooms/private lodgings & Total facilities & 2018 & 19 & Fac. \\
\hline guest rooms/private lodgings & Total beds & 2016 & 191 & Bed \\
\hline guest rooms/private lodgings & Total beds & 2018 & 420 & Bed \\
\hline agritourism lodging & Total facilities & 2016 & 26 & Fac. \\
\hline agritourism lodging & Total facilities & 2018 & 26 & Fac. \\
\hline agritourism lodging & Total beds & 2016 & 439 & Bed \\
\hline agritourism lodging & Total beds & 2018 & 447 & Bed \\
\hline $\begin{array}{l}\text { other tourist accommodation } \\
\text { establishments }\end{array}$ & Total facilities & 2016 & 22 & Fac. \\
\hline $\begin{array}{l}\text { other tourist accommodation } \\
\text { establishments }\end{array}$ & Total facilities & 2018 & 22 & Fac. \\
\hline $\begin{array}{l}\text { other tourist accommodation } \\
\text { establishments }\end{array}$ & Total beds & 2016 & 749 & Bed \\
\hline $\begin{array}{l}\text { other tourist accommodation } \\
\text { establishments }\end{array}$ & Total beds & 2018 & 799 & bed \\
\hline
\end{tabular}

Source: Local Data Bank of the Statistical Office, https://bdl.stat.gov.pl (11.09.2019).

As at the end of July 2018, the largest (4824) beds were in hotels (increase by $4,6 \%$ compared to 2016 and quite significant compared to 2017 - by 10,1\%). In other hotel facilities, the number of beds decreased, compared to 2016, the most in motels (by 6,6\%). In the remaining six tourist accommodation establishments, the number of beds increased (the largest, more than double, in guest rooms), while in the other facilities there was a decrease, among others: on camping sites - by $29,1 \%$, in training and recreation centres - by $8,3 \%$, in tourist cottage complexes - by $7,6 \%$, in holiday resorts - by $6,4 \%$, or in agritourism lodgings - by 7,6\%. This resulted in a decrease in the total number of beds in the voivodeship by 2,7\% compared to the state recorded on July 31, 2016 (Tourism in the Lubuskie Voivodeship in 2016-2018, Statistical Office in Zielona Góra, 2019).

In terms of tourist infrastructure development, the Lubuskie Voivodeship is not uniform. The most, because over $60 \%$ of tourist accommodation establishments operate in the northern and central parts of the voivodeship (the exception is the Wschowski district). In July 2018 (with an average number of 21 facilities per one district), the largest number of tourist accommodation facilities were located in Międzyrzecki (39), Świebodziński (38), Słubicki (31), Zielona Góra (31), Wschowa (27) and Sulęcinski (26), while the least in the Żagań poviat (6) 
and in the Nowosolski poviat (10 objects) (Tourism in the Lubuskie Voivodeship in 2016-2018, Statistical Office in Zielona Góra, 2019).

During the research, it was noticed that the attractiveness of accommodation facilities is largely influenced by catering facilities.

In 2018, 687,8 thousand of tourists stayed in tourist accommodation establishments. It was $4,0 \%$ more than last year and $7,2 \%$ more than in 2016 , which was granted 1429,5 thousand of accommodation. There was an increase both in annual terms and in relation to 2016 by $5,0 \%$ and $3,0 \%$. $74,2 \%$ (510,1 thousand) of the total number of tourists accommodated in tourist accommodation establishments were foreign tourists, and 25,8\% (177,6 thousand) were foreign tourists.

The use of tourist accommodation facilities is expressed by the degree of use of beds and the degree of use of rooms in hotel facilities (i.e. the percentage share of the number of overnight stays allocated to the nominal number of beds and rented rooms - to the nominal number of rooms in hotel facilities). The degree of occupancy of beds, on average $29,8 \%$, increased by $1,0 \mathrm{pp}$. compared to both the one recorded in 2016 and compared to 2017. In the period 2016-2018, the largest increase in the degree of use of beds occurred in camping sites by 6,5 percentage points, and the lowest in motels, where there was an increase of $0,5 \mathrm{pp}$. The decrease in the occupancy rate of beds took place, among others in: school youth hostels by $11,7 \mathrm{pp}$., holiday centres by $6,6 \mathrm{pp}$, campsites by $3,3 \mathrm{pp}$. and training and recreation centres by 3,0 pp. The use of rooms in hotel facilities during 2018 amounted to 37,7\%, i.e. by $2,0 \mathrm{pp}$. more in relation to 2016 and by 0,5 percentage points less compared to 2017 . The highest level of room use in hotels, motels, boarding houses and other hotel facilities was recorded in August $-46,1 \%$, and the lowest in January $-28,8 \%$ (Tourism in the Lubuskie Voivodeship in 2016-2018, Statistical Office in Zielona Góra, 2019).

Table 3 shows that the Lubuskie Voivodeship in terms of the use of bed places and the degree of use of hotel rooms ranks last compared to all the provinces. An upward trend can be observed compared to 2018 to 2016.

Table 3.

Occupancy rate of beds and occupancy rate of hotel rooms in individual voivodeships

\begin{tabular}{|c|c|c|c|c|}
\hline \multirow{3}{*}{ Name } & \multicolumn{2}{|c|}{$\frac{\text { occupancy rate of beds }}{\text { In total }}$} & \multicolumn{2}{|c|}{$\frac{\text { occupancy rate of rooms }}{\text { In total }}$} \\
\hline & 2016 & 2018 & 2016 & 2018 \\
\hline & {$[\%]$} & {$[\%]$} & {$[\%]$} & {$[\%]$} \\
\hline POLAND & 38,6 & 40,8 & 47,6 & 49,8 \\
\hline DOLNOŚLĄSKIE & 37,0 & 39,9 & 45,7 & 47,7 \\
\hline KUJAWSKO-POMORSKIE & 33,2 & 32,5 & 43,0 & 43,6 \\
\hline LUBELSKIE & 29,1 & 30,4 & 36,8 & 38,9 \\
\hline LUBUSKIE & 28,2 & 31,2 & 35,7 & 37,7 \\
\hline ŁÓDZKIE & 31,7 & 35,0 & 41,5 & 45,5 \\
\hline MAŁOPOLSKIE & 45,6 & 47,9 & 54,3 & 56,1 \\
\hline MAZOWIECKIE & 47,4 & 47,8 & 59,5 & 60,4 \\
\hline OPOLSKIE & 29,7 & 32,9 & 39,6 & 42,0 \\
\hline
\end{tabular}


Cont. table 3.

\begin{tabular}{|l|r|r|r|r|}
\hline PODKARPACKIE & 30,0 & 31,6 & 36,6 & 39,3 \\
\hline PODLASKIE & 31,3 & 31,8 & 38,7 & 40,4 \\
\hline POMORSKIE & 41,8 & 44,7 & 50,7 & 53,6 \\
\hline ŚLA_SKIE & 34,7 & 39,2 & 43,8 & 48,8 \\
\hline ŚWIETOKRZYSKIE & 27,8 & 31,7 & 35,1 & 39,8 \\
\hline WARMIŃSKO-MAZURSKIE & 35,3 & 34,4 & 39,9 & 38,9 \\
\hline WIELKOPOLSKIE & 31,2 & 32,7 & 42,1 & 43,0 \\
\hline ZACHODNIOPOMORSKIE & 49,6 & 51,6 & 57,8 & 58,7 \\
\hline
\end{tabular}

Source: Local Data Bank of the Statistical Office, https://bdl.stat.gov.pl (11.09.2019).

Nowadays, it is very important to attract and encourage foreign tourists to visit and stay in a particular region. Table 4 shows that from year to year there are more and more foreign tourists in Lubuskie, where in 2018 there were 177,6 thousand of foreign tourists.

During this time, 687,8 thousand of tourists stayed in tourist accommodation establishments in the Lubuskie Voivodeship, which constituted 4,0\% more than a year ago and 7,2\% more than in 2016, which was granted 1429,5 thousand of accommodation. It was an increase both in annual terms and in relation to 2016 by 5,0\% and 3,0\%. (Tourism in the Lubuskie Voivodeship in 2016-2018, Statistical Office in Zielona Góra, 2019).

Table 4.

Number of foreign tourists and accommodation provided to foreign tourists in individual voivodeships

\begin{tabular}{|c|c|c|c|c|c|c|}
\hline \multirow{4}{*}{ Name } & \multicolumn{3}{|c|}{ foreign tourists (non-residents) } & \multirow{2}{*}{\multicolumn{3}{|c|}{$\begin{array}{c}\text { accommodation granted to foreign } \\
\text { tourists (non-residents) }\end{array}$}} \\
\hline & \multicolumn{3}{|c|}{ In total } & & & \\
\hline & 2016 & 2017 & 2018 & 2016 & 2017 & 2018 \\
\hline & [person] & [person] & [person] & {$[-]$} & {$[-]$} & {$[-]$} \\
\hline POLAND & 6378793 & 6803667 & 7082231 & 15579225 & 16705215 & 17742651 \\
\hline DOLNOŚLASKIE & 593482 & 654991 & 696726 & 1347103 & 1442076 & 1483890 \\
\hline KUJAWSKO-POMORSKIE & 120510 & 120711 & 116637 & 282924 & 290642 & 279631 \\
\hline LUBELSKIE & 120767 & 129533 & 126390 & 188477 & 211183 & 215750 \\
\hline LUBUSKIE & 154096 & 171966 & 177639 & 300484 & 331764 & 327190 \\
\hline ŁÓDZKIE & 175063 & 189561 & 194876 & 344725 & 364930 & 531483 \\
\hline MAŁOPOLSKIE & 1376883 & 1460023 & 1504318 & 3328387 & 3553368 & 3652754 \\
\hline MAZOWIECKIE & 1476815 & 1547305 & 1588719 & 2777517 & 3016383 & 3143832 \\
\hline OPOLSKIE & 48097 & 48010 & 54454 & 109592 & 107086 & 108909 \\
\hline PODKARPACKIE & 138552 & 162691 & 151037 & 259276 & 303657 & 291635 \\
\hline PODLASKIE & 168807 & 162872 & 145137 & 218494 & 220602 & 199203 \\
\hline POMORSKIE & 504565 & 559741 & 572393 & 1269566 & 1450879 & 1542129 \\
\hline ŚLĄSKIE & 366956 & 374751 & 422025 & 800131 & 829962 & 967481 \\
\hline ŚWIĘTOKRZYSKIE & 32748 & 34716 & 36984 & 74453 & 81883 & 105595 \\
\hline $\begin{array}{l}\text { WARMIŃSKO- } \\
\text { MAZURSKIE }\end{array}$ & 160199 & 641 & 162345 & 401127 & 400048 & 395204 \\
\hline WIELKOPOLSKIE & 303291 & 307628 & 310980 & 613057 & 639231 & 663667 \\
\hline ZACHODNIOPOMORSKIE & 637962 & 711527 & 821571 & 3263912 & 3461521 & 3834298 \\
\hline
\end{tabular}

Source: Local Data Bank of the Statistical Office, https://bdl.stat.gov.pl (11.09.2019).

The largest number of foreign tourists visiting the Lubuskie Voivodeship came from Europe $-173,5$ thousand, where $67,0 \%$ are citizens of the European Union, i.e. 3,5\% more than a year ago. Europeans constituted $97.6 \%$ of the total foreign tourists. It was a decrease of 0.2 percentage points compared to 2016. The inhabitants of Europe visiting in 2018 the 
Lubuskie Voivodeship came mainly from Germany - 30,9\%. There was also a high percentage of tourists from Russia - 11,2\%, Ukraine - 10,3\%, Belarus - 9,9\%, Lithuania - 9,5\% and Latvia $-6,9 \%$. Tourists from the Netherlands 3,9\%, Great Britain - 2,5\%, France - 2,2\%, Denmark 1,8\% and Belgium 1,4\% also visited the Lubuskie Voivodeship. Moreover, in Lubuskie tourist accommodation facilities there were, among others, 2,1 thousand of tourists from North America, 1,5 thousand - from Asia, 0,3 thousand - from South and Central America, 0,2 thousand - from Africa and 0,1 thousand - from Australia and Oceania. (https://zielonagora.stat.gov.pl/dla-mediow/informacje-prasowe/informacjaprasowanipublikacja-turystyka-w-wojewodztwa-lubuskim-w-latach-2016-2018,131.html, 24/09/2019).

\subsection{Determinants of the region's natural competitiveness}

Competitiveness can be defined as the region's ability to adapt to changing environmental conditions, which is to contribute to success. Achieving a competitive advantage over other regions based on the existing environmental potential, the ability to use it in the processes of socio-economic growth and development, and a low level of anthropopressure can be described as the region's environmental competitiveness. This phenomenon should be considered in two-way terms. On the one hand, competitive advantage may relate to environmental conditions occurring in a particular region, on the other hand, the key here is the ability to transform them into socio-economic effects that will contribute to the relatively faster development of the region in question.

The categorization of environmental determinants of the regions' competitiveness can be divided into:

1. Natural conditions: landscape diversity (e.g. occurrence of mountainous areas, rivers, lakes); average monthly air temperatures; monthly precipitation; wind speed; degree of sunshine and cloudiness; occurrence of resources of more important minerals (e.g. hard coal and lignite, gas, oil).

2. Geodetic and soil conditions: geodetic structure of the voivodeship (e.g. share of agricultural land, forest land in the total area of the voivodeship); soil structure according to bonitation classes; threat associated with wind, water and ravine erosion; the share of devastated and degraded land; fertilizer consumption level; soil reaction structure.

3. Condition and degree of pollution of water resources: surface water resources; groundwater exploitation resources; surface and underground water quality, including cleanliness of lakes and rivers; industrial and municipal sewage discharged into water and soil (including untreated sewage, amount of sewage sludge generated). 
4. Quality and level of atmospheric air pollution: concentration level of basic air pollutants; UV-B radiation level; structure of pollution concentration zones; ozone content in the atmosphere; chemical composition of atmospheric precipitation; total air pollution, including the number of particularly onerous plants; impurities retained and neutralized in purifying devices.

5. The level and structure of generated waste.

6. Facilities and areas with special natural values as well as the degree of forest cover and afforestation of land.

7. Industrial and road noise level.

8. Infrastructure for environmental protection and water management: level of equipment in the sewage network; sewage treatment plants serving cities and villages; population using sewage treatment plants; equipped with devices to protect against air pollution; the ratio of legal landfills to the so-called illegal dumps (Kasztelan, 2010, p. 83).

The definition of a region's competitiveness often defines the ability to achieve relatively high incomes, i.e. ensuring a fair standard of living for the inhabitants of a particular region. The basic indicator of the purely economic nature of GDP per capita is often used to examine this phenomenon, and the factor that affects the region's competitiveness, which is the natural environment, is omitted.

Some definitions of competitiveness emphasize the strong relationship between competitiveness and prosperity and define a competitive region not only through the prism of factors related to production, but also in relation to the whole economic situation and its important element, which is a lasting and growing level of prosperity. Building a competitive region is not fast and easy. It is a long and complex process. Unlike the company's competitiveness, there are no fixed and unambiguous measures for regions that represent the best level of competitiveness (Sługocki, 2016, pp. 552-554).

Hanna Kruk, conducting her analysis, stated that the tourist attractiveness of the region is influenced not only by the occurrence of areas with high natural values, assessing waters or forests, but their proper development for the needs of tourism and promotion of the region (Kruk, 2010, p. 196).

The regions' natural competitiveness should be understood as a concept closely related to the natural environment as a factor of competitiveness. This is the relationship between the natural environment and the activities of economic operators using this factor. It should be remembered by managing the resources and values of the natural environment in the region that they are economic goods, not free. A large part will naturally run out, while others will be destroyed as a result of poorly planned activities and will disappear (Kruk, 2010, pp. 201, 235-236). 


\section{Conclusions}

The tourist attractiveness of the Lubuskie Voivodeship is underestimated. The attractiveness of a particular region is definitely determined by natural values, preparation of the area for tourism and recreation, as well as the availability of particularly valuable cultural and national heritage. A very important element is the communication infrastructure, because the means of road and rail transport are most often used by tourists.

The tourist potential of the Lubuskie Voivodeship is certainly huge but not fully utilized. The Lubuskie Voivodeship is distinguished by its special natural values, above all the varied landscape, large forest complexes, numerous lakes and rich fauna and flora. The natural environment of the voivodeship is slightly transformed and not polluted.

The richness of the voivodeship are forests and wilderness, with numerous landscape parks, reserves and monuments of nature as well as with animals living in the wild. An important aspect in the tourist landscape of the Lubuskie Voivodeship are castles, churches and manor houses and palaces related to the history of the region. Today, a large proportion of tourists seek to learn about folklore, tradition, folk creativity, as well as regional cuisine. The voivodeship offers a wide range of cultural, sporting, entertainment and artistic events.

It should be added that as one of the few regions in Poland, the Lubuskie Voivodeship may offer enotourism as an attraction (Dariusz, 2019). The Lubuskie Land is called the land of flowing wine and honey, due to the exceptionally mild climate, necessary to found a vineyard and many regional products. The Lubuski Wine and Honey Trail is the first such attraction in Poland. The over 200-kilometer route includes 14 stops, which consist of vineyards, museums and farms, where you can taste regional delicacies, taste the wine products and even spend the night.

A showcase of this form of recreation is the only "living" wine museum in Poland Lubuskie Wine Center in Zabór near Zielona Góra. The main goal of creating the Lubuskie Wine Centre is the development of the brand and tourist potential of the Lubuskie Voivodeship as well as building regional identity, integration of wine environments and re-cultivation of traditions related to viticulture and wine production in the Lubuskie Region.

The Lubuskie Land and its special natural values with numerous monuments make this area more beautiful from Polish regions, which has been attracting domestic and foreign tourists for years. 


\section{References}

1. Dariusz, Ch., Lubuskie winnice. Jako jeden z nielicznych regionów w Polsce możemy zaproponować jako atrakcję - enoturystykę. Gazeta Lubuska, 09.05.2019.

2. Demidowicz, M., Konopczyński, W., Charakterystyka Województwa Lubelskiego. Stan środowiska w woj. Lubuskim na 2006, 9, http://www.zgora.pios.gov.pl/wios/images/stories/ pms/pub/2006/1_charakterystyka.pdf, 22.09.2019.

3. Kasztelan, A. (2010). Środowiskowa konkurencyjność regionów - próba konceptualizacji. Problemy Ekorozwoju/Problems of Sustainable Development, 2, 77-86.

4. Kondracki, J. (1978). Geografia fizyczna Polski. Warszawa: PWN, 149.

5. Kozłowski, S. (1983). Przyrodnicze uwarunkowania gospodarki przestrzennej Polski. Wrocław: Wszechnica Polskiej Akademii Nauk, 82.

6. Kruk, H. (2010). Przyrodnicza konkurencyjność regionów. Toruń.

7. Local Data Bank of the Statistical Office, https://bdl.stat.gov.pl, 11.09.2019.

8. Macias, A., Bródka, S. (2014). Przyrodnicze podstawy gospodarowania przestrzenia. Warszawa: PWN, 136.

9. Przemysław, S., Demidowicz, M., Konopczyński, W. (2018). Stan środowiska $w$ województwie lubuskim $w$ latach 2016-2017. Zielona Góra: Wojewódzki Inspektorat Ochrony Środowiska, 9.

10. Sługocki, W. (2016). Rola funduszy Unii Europejskiej w budowaniu konkurencyjności polskich regionów. Marketing i Rynek, 10.

11. Starkel, L. (1991). Geografia Polski. Środowisko Przyrodnicze. Warszawa: PWN, 17.

12. Statistical Office in Zielona Góra, 30.05.2018.

13. Tourism in the Lubuskie Voivodeship in 2016-2018 (2019). Statistical Office in Zielona Góra.

14. Turyści w Lubuskiem, https://zielonagora.wyborcza.pl/zielonagora/7,35182,24979834, turysci-w-lubuskiem w-ub-roku-nocowalo-tu-blisko-700-tys.html, 16.09.2019.

15. Zamek $w$ Łagowie - dawna siedziba Joannitów, https://www.styl.pl/podroze/news-zamekw-lagowie-dawna-siedziba-joannitow,nId,2535399, 22.09.2019.

16. Zbieraj się. 5 naturalnych powodów by lubić lubuskie, https://zbierajsie.p1/5-powodowlubic-lubuskie/, 22.09.2019. 